\title{
GÊNERO, HEROÍSMO E PATRIOTISMO EM OBRAS DE LITERATURA PARA CRIANÇAS
}

\author{
Rosa Maria Hessel Silveira \\ PPGEDU-ULBRA e PPGEDU-UFRGS \\ rosamhs@terra.com.br \\ Iara Tatiana Bonin \\ PPGEDU-ULBRA \\ iara_bonin@yahoo.com.br
}

\section{RESUMO:}

No presente artigo analisamos representações de mulher presentes em obras literárias destinadas a crianças escolarizadas das primeiras décadas do século XX: Culto Cívico, escrita por João Roque Moreira Gomes, que circulou entre professores sul-riograndenses, e Heroínas e Mártires Brasileiras, de autoria de Renato Sêneca Fleury, dedicada principalmente a meninas leitoras. Estas coletâneas de poesia e prosa são marcadas por um ideário patriótico e forte inspiração cívica, valores característicos do período. Através de uma análise discursiva, buscamos delinear certo perfil feminino, observando que nos textos examinados figuram mulheres devotadas ao lar e à família, que assumem a maternidade como condição natural e que educam os filhos para o patriotismo, a honradez e o respeito às instituições legais. Figuram ainda mulheres heroínas que, em contextos de guerra, assumem frentes de combate, lutando ao lado de seus maridos, ou ainda, como mulheres consagradas à caridade, atuam em hospitais de campanha, cuidando dos soldados com zelo maternal. Tais obras apresentam e enaltecem acontecimentos protagonizados por mulheres e homens e, através de exemplos edificantes, colaboram para naturalizar determinados atributos femininos, ensinando sobre patriotismo e sobre práticas desejáveis naquele contexto histórico.

Palavras-chave: literatura infantil - representações de gênero - patriotismo

\section{GENDER, HEROISM AND PATRIOTISM IN CHILDREN'S LITERATURE}

\begin{abstract}
:
In this paper we have analysed women's representations present in schooled children's literature in the early twentieth century: Culto Cívico by João Roque Moreira Gomes, which circulated among teachers in Rio Grande do Sul, Brazil, and Heroínas e Mártires Brasileiras by Renato Sêneca Fleury targeted at children readers. These sets of prose and poetry are marked by a patriotic ideology and strong civic inspiration, values that were typical of that period. Through a discursive analysis, we have sought to provide a particular female profile, noting that in the examined texts there are women dedicated to home and family, who accept motherhood as a natural condition and raise children for patriotism, honour and respect of legal institutions. There are also heroine women who are on the battle front fighting with their husbands in contexts of war, or even women devoted to charity, taking care of soldiers with maternal zeal in camp hospitals. These works present and exalt events women and men have led, and by edifying examples, they help to naturalise particular female attributes, teaching about patriotism and practices useful on that historical context.
\end{abstract}

Keywords: children's literature - gender representations - patriotism 
O surgimento da literatura infantil, no mundo ocidental, esteve associado à própria constituição da infância como uma etapa específica da vida, ou seja, ao entendimento de que crianças são sujeitos a serem educados, tutelados, ensinados e formados. Ariès, em conhecido estudo, propôs a tese de que a interpretação cultural da infância sofreu profundas mudanças no mundo ocidental desde o século XVII e Shavit (2003), entre outros autores, explorou os nexos que se pode identificar entre essa mudança cultural e o florescimento da literatura para crianças na Europa. Especificamente, a autora estabelece uma relação entre uma segunda noção de infância (a primeira teria sido a de que crianças eram seres dotados de "inocência, doçura e outras qualidades angélicas") e a emergência de uma literatura a elas destinada. Afirma a autora (2003, p.26-27) sobre a segunda noção de infância:

Esta noção preocupava-se principalmente com o bem-estar espiritual da criança e defendia que as crianças deviam ser educadas e disciplinadas; além disso, ela prescrevia um novo papel para os adultos segundo o qual estes eram responsáveis pelo bem estar espiritual da criança. (...) As crianças eram agora encaradas como criaturas delicadas que tinham de ser reformadas e salvaguardadas; e a maneira de as reformar era através da educação e através de livros produzidos primariamente como veículos pedagógicos. (...) Esta segunda noção de criança - a educativa - acabou por fornecer o enquadramento para a literatura para crianças canonizada. Isto é, desde o seu início, os livros para crianças foram escritos com uma certa idéia da criança em mente; quando esta idéia mudou, os textos para crianças também mudaram.

Ora: tal enquadramento dos livros para crianças perdurou e, de certo modo, ainda perdura na literatura infantil. Ideais de cidadãos/ãs a formar, representações de crianças (incluindo de sua competência, sua sensibilidade, sua vontade), entendimentos do melhor caminho para formarmos os infantes tendo em vista tais ideais se articulam para influenciarem as concepções do que seja um livro adequado para a infância, em diferentes momentos e contextos, desde sua "invenção".

Pois bem: é sobre tal pano de fundo que iniciamos o presente trabalho. Ele se ancora, também, na constatação de que os livros brasileiros para crianças e jovens estiveram, a partir do final do século XIX e por várias décadas do século XX, presos a uma missão de formar cidadãos e cidadãs para uma nova nação republicana (o Brasil), que valorizassem o trabalho, o estudo, as virtudes morais e o "amor à pátria" - requisitos que, então, se nominavam como imprescindíveis para tal construção nacional (certamente, atributos como espontaneidade, autonomia e o atualíssimo "espírito de empreendedorismo" não corresponderiam ao espírito da época...).

Efetivamente, as primeiras décadas do século XX, no Brasil, foram marcadas pela emergência de um projeto civilizador associado à idéia do progresso, da necessidade de modernização da nação, vista como mergulhada num atraso secular, e de sedimentação dos valores do regime republicano, todas essas dimensões articuladas entre si. Dentro desse quadro, a educação adquiria uma visibilidade inusitada, como relembra Souza (1998, p. 15): "Os republicanos mitificaram o poder da educação a tal ponto que depositaram nela não apenas a esperança de consolidação do novo regime, mas a regeneração da Nação". A autora enfatiza o quanto a crença na ação redentora da educação inspirou, na época, ações políticas e legais, como a instituição dos grupos escolares (nova e revolucionária 
organização administrativo-pedagógica), a promoção de conferências educacionais, a criação de escolas populares, de cursos noturnos para adultos e de escolas profissionais, entre outros. E não apenas alfabetizar e instruir stricto sensu constituíam a missão escolar propriamente dita. Assim, Souza (1998, p. 28) ainda observa que, no início da República, "a escola primária adquire uma finalidade cívica, moral e instrumental". Ou seja: a educação popular (do povo) "foi associada ao projeto de controle e ordem social, a civilização vista da perspectiva da suavização das maneiras, da polidez, da civilidade e da dulcificação dos costumes" (id., p. 27). De maneira especial, a função de construção e reforço ao civismo ocupará um importante lugar na educação brasileira das primeiras décadas do século XX: os exames públicos, a exploração e exibição exaustiva de símbolos nacionais, como a bandeira, as próprias comemorações cívicas, a produção abundante de material escolar (incluindo manuais e livros de leitura) eivado de ufanismo demonstram a incorporação, pela escola e pelo aparato pedagógico, dessa função nacionalizadora e patriótica central.

No delineamento de aspectos culturais e sociais relevantes dessa quadra da história brasileira, não se pode menosprezar a importância da presença do ideário positivista. Como observa Carvalho (1990), os positivistas constituíram o "grupo mais ativo, mais beligerante, no que diz respeito à tentativa de tornar a República um regime não só aceito como também amado pela população. Suas armas foram a palavra escrita e os símbolos cívicos" (p. 129). Influenciando nas concepções políticas e também nas pedagógicas, imbuídos pela convicção de que o Brasil deveria ser impulsionado para apressar "a marcha da história", ecos do ideário positivista percorrem manuais didáticos e livros de leitura de então, às vezes amalgamados com concepções religiosas tradicionais.

E é dentro desse quadro mais geral que se situam as duas obras sobre as quais nos debruçamos no presente artigo: a primeira, intitulada Culto Cívico, escrita por João Roque Moreira Gomes nas primeiras décadas do século XX, e a segunda, com o título Heroínas e Mártires Brasileiras, de autoria de Renato Sêneca Fleury, editada provavelmente entre os anos 1940 e 1960.

Por que a escolha de tais obras? Elas chegaram às nossas mãos através de exemplares de herança familiar, com marcas de uso escolar e extra-escolar, e sua leitura mostrando regularidade e dispersões - nos inspirou uma investigação que buscasse as imagens de mulher produzidas em alguns de seus textos. São obras marcadas por uma inspiração cívica, por vezes extremada, e foram produzidas em momentos, como acima referimos, em que se buscava estabelecer um ideário patriótico articulado a um tipo de cidadania profundamente ufanista. Assim, através de uma análise discursiva, que considera tanto a superfície do texto, quanto os cânones estéticos então vigentes para esses gêneros textuais, buscamos delinear certo perfil feminino produzido neste contexto cívico das primeiras décadas do século XX. Valemo-nos, neste sentido, do conceito de representação, tal como ele vem sendo trabalhado no contexto dos Estudos Culturais. Conforme Hall (1997)

a representação é o processo pelo qual membros de uma cultura usam a linguagem para instituir significados. Essa definição carrega uma premissa: as coisas, os objetos, os eventos do mundo não tem, neles mesmos, qualquer sentido fixo, final ou verdadeiro. Somos nós, em sociedade, entre culturas humanas, que atribuímos sentidos às coisas. Os sentidos, consequentemente, sempre mudarão de uma cultura para outra e de uma época para outra (p. 61). ${ }^{1}$ 
Assim sendo, as representações possibilitam, de maneira provisória e contingente, que nos reconheçamos em certas identidades e que possamos demarcar limites entre aquilo que somos/pensamos ser e o que imaginamos serem os outros. Também para Silva (2000, p. 97), na "análise cultural mais recente, [a representação] refere-se às formas textuais e visuais através das quais se descrevem os diferentes grupos culturais e suas características". Ou seja, entendemos que, através dos textos, se plasmam e se comunicam determinados modos de entender o feminino, apresentados como desejáveis, modelares, enfim, normais, no sentido de legitimarem um determinado padrão esperável - a norma.

De alguma forma, é possível tecer relações entre o conceito de representação, aqui utilizado, e o de ideologia, feitas as ressalvas que seguem. Dentro do referencial teórico que utilizamos, é preciso que nos distanciemos da concepção da "ideologia como falsa consciência", ou como uma forma de encobrimento da verdade, o que suporia, conforme Silva (2000, p. 69), um confronto entre ideologia e um conhecimento supostamente verdadeiro. A partir da visão dos Estudos Culturais, as representações não podem ser classificadas como ideológicas ou não, ou, mesmo, como mais ou menos ideológicas, uma vez que se postula não haver um posto privilegiado de observação, externo ao discurso, que permita ao enunciador distinguir o que é "real", "verdadeiro", do que é "falso", "mentiroso". Para, então, articularmos com propriedade o conceito de representação cultural com o de ideologia, seria preciso considerarmos o que Hartley relata (2004, p. 133), em relação à re-teorização do conceito, que teria levado à idéia da ideologia em geral. Neste sentido, afirma o autor:

Ela [a noção de ideologia em geral] implica que todo o conhecimento científico ou outro é produzido dentro da linguagem, e que a linguagem nunca é um meio transparente através do qual a verdade possa ser observada. Por conseguinte, toda a linguagem é vista como ideológica e a verdade, como um produto, e não como motivador da linguagem. Disso decorre que nenhum discurso específico (incluindo o próprio marxismo) está isento de ideologia. Em vez disso, há sempre uma série de discursos ideológicos contraditórios dentro de uma formação social global, e aquilo que está em jogo na forma como eles são produzidos, desenvolvidos, regulados, institucionalizados e resistidos é não só o conhecimento, mas também o poder.

É por essa razão que, nas análises culturais, o que se leva em conta são as políticas representacionais, isto é, as maneiras como os discursos se articulam, conferindo legitimidade a certas representações, e como vão sendo referendadas, replicadas, contestadas certas verdades, em práticas de distintos grupos sociais. Em tais políticas há sempre uma assimetria entre aqueles que estão autorizados a falar, a narrar e a representar e aqueles que são descritos, posicionados e representados.

Estabelecidas essas ressalvas teóricas introdutórias, passamos ao exame mais circunstanciado das obras escolhidas e à análise propriamente dita.

\section{Um pouco mais sobre as obras analisadas}

Culto Cívico consiste em alentada coletânea de textos que circulou entre professores sul-rio-grandenses nas primeiras décadas do século XX. Conforme Martins (1978), a obra teria sido editada pela Livraria Americana, de Rio Grande (RS), em sucessivas edições, sendo que a última dataria de $1930^{2}$. Seu autor, João Roque Moreira Gomes, foi inspetor de instrução pública da $3^{\text {a }}$. Região Escolar e, em 1909, apresentou 
relatório sobre a referida região ao Inspetor Geral da Instrução Pública da Província ${ }^{3}$, no qual manifestava preocupação com o fato de poucas escolas particulares da região, na época, ministrarem noções de português, sendo o ensino ministrado em alemão. A breve informação que temos sobre sua atuação no cenário educativo gaúcho parece se coadunar com a preocupação nacionalista que perpassa a coletânea por ele organizada e que, aliás, em nada foge ao espírito da Primeira República.

O exemplar de que nos servimos, tardiamente encadernado, não contém a folha de rosto nem as 10 primeiras folhas, assim como não possui todo o sumário. Mesmo assim, trata-se de alentado volume, que pertenceu a e foi usado por uma professora federal de primeiras letras que exerceu sua docência tanto em aulas públicas quanto em escolas confessionais do Vale do Taquari (RS), a partir de 1918 até a década de 1940. Algumas anotações e sinais à margem de alguns textos - nomes de alunos, série escolar, datas sugerem que o livro deve ter sido usado como fonte de textos para trabalho em aula ou utilização em eventos escolares, por longo tempo.

A edição com que trabalhamos possui 383 páginas e dezenas de textos - em prosa ou poesia - cuja autoria é referida apenas no Índice, com as seguintes subdivisões: Hymnos, A Bandeira do Brasil - Prosa, Poesias à Bandeira, Canções Patrióticas, Poesias à Pátria Brasileira. Entre as dezenas de autores, tanto se alinham Olavo Bilac, Coelho Netto, José do Patrocínio, Fagundes Varela, Casemiro de Abreu, Gonçalves Dias, conde Affonso Celso, nomes conhecidos nacionalmente no campo da literatura e/ou político, como outros, numerosos, cuja memória as décadas apagaram ou esmaeceram e que aparecem, por vezes, antecedidos por seus epítetos, obviamente de prestígio na sociedade de então: Padre João de Deus, Tenente Cyro de Andrade, D. Delminda de Souza, Dr. Pedro Vergara, Visconde Araguaya, etc.

Um espírito cívico exacerbado atravessa toda a coletânea e, de maneira geral, o patriotismo parece ser quase reduzido ao espírito bélico em que se corporificaria o amor incondicional à Pátria, atestado pela adesão à batalha contra o inimigo com o sacrifício da própria vida. Os títulos dos textos - em prosa ou verso - são sugestivos deste espírito: $A$ Pátria / A Pátria e a humanidade / Pátria e escola /Meu Brasil / Amor da Pátria / Sou Brasileiro/ e um destaque especial é dado à Bandeira Nacional - as páginas que vão da 183 à 236 (mais de 50) são dedicadas apenas a poemas, hinos ou breves textos em prosa que glorificam, interpretam e pregam o culto à bandeira nacional.

Tal valoração do militarismo também está presente em outras produções para crianças da época. Leão (2007), em artigo dedicado a analisar livros, impressos e leituras infantis de 1890 a 1915, afirma, com certa ironia, a partir da análise da revista infantil Tico-Tico da primeira década do século XX, que circulou com sucesso por várias décadas no Brasil:

Tudo o que os meninos leitores mais desejavam era assentar praça para defender a pátria. Daí, elaborarem, nas cartas que enviavam ao Tico-Tico, uma auto-imagem de "pequenos oficiais" revelando formas de identificação e idealização das figuras adultas. As narrativas de verniz memorialista que os mais velhos guardavam no culto aos feitos heróicos dos soldados na Guerra do Paraguai formavam as imagens preferidas da criançada. O poeta Olavo Bilac realizava essa operação sentimental em seus versos e contos pátrios. (p.4)

Como adiante veremos, essa "operação sentimental" patriótica se espraiava por várias obras dedicadas à infância, compondo um cenário onde também seria necessário 
encontrar um lugar para o gênero feminino, o qual, nos moldes de então, não se julgava adequado para o confronto bélico.

Tal como o título do livro sugere, o amor à Pátria é equiparado a uma religião (Oração à Bandeira / Oração à Pátria são alguns títulos) ou é conectado de forma íntima ao espírito religioso católico (o patriotismo, aí, não é laico); a presença de religiosos como autores de alguns textos já seria um indicativo dessa íntima aproximação, mas alguns títulos também nos sugerem tal articulação: Pátria para Cristo / O Brasil e a Cruz / Deus salve a Pátria / Hino Lar, Pátria e Deus/ Canção dos Templários.

As ilustrações, pouco numerosas e em branco e preto, focalizam os chamados "vultos pátrios", com destaque para heróis militares e políticos de projeção, todos homens, ora de projeção nacional (José Bonifácio, por exemplo) ora de importância estadual (Júlio de Castilhos, p.ex.); encontramos, ainda, algumas raras reproduções de quadros célebres, como Primeira Missa no Brasil, Batalha do Riachuelo, Batalha do Avaí.

A maioria dos textos em prosa e dos poemas (aí incluídos os numerosos hinos, possivelmente compostos para serem cantados) mostra uma influência muito grande da estética e gosto parnasiano: frases em ordem inversa, vocábulos raros, alguns próximos às vertentes latinas, imagens grandiloqüentes, referências às mitologias clássicas, por vezes. Não são exclusivos, portanto, dos textos que analisaremos.

Já a segunda obra analisada - Heroínas e Mártires Brasileiras - se insere no veio biográfico da literatura infanto-juvenil brasileira: compõe a série Grandes Brasileiros, que é descrita, no próprio livro, como trazendo "vultos eminentes do Brasil carinhosamente biografados em linguagem adequada à infância e juventude, numa coleção plena de exemplos edificantes de estudo, de heroísmo e de amor pátrio". A exemplo de outras coletâneas, também esta se propunha a trazer condutas e valores considerados exemplares, em biografias de personagens históricos. Na apresentação do livro, o autor destaca que ele é principalmente dedicado à juventude feminina do Brasil, mas pode ser lido por todo e qualquer brasileiro, para enaltecer o amor patriótico. Analisando obras desse escritor, Lajolo \& Zilberman (1985, p. 117), afirmam que "nos diferentes livros [biográficos] a finalidade parece ser uma só: organizar um elenco de nomes ilustres que reforce o sentimento patriótico e sirva de exemplo aos leitores".

Numa época em que o nacionalismo era em grande parte construído pela menção às conquistas e guerras em que se envolvera o Brasil, mesmo quando era apenas colônia, não seria uma tarefa fácil a organização de uma obra que colocasse em destaque personagens femininas que pudessem ser consideradas heroínas. Assumindo esta tarefa, o autor reuniu 16 histórias de mulheres que, de algum modo, se destacaram em situações de confrontos e batalhas em defesa do território brasileiro (com algumas exceções de mulheres que definham de tristeza pela separação de seus amados - maridos, pais). As heroínas são descritas a partir de certos atributos que as tornariam diferenciadas de outras mulheres de seu tempo, em especial bravura, lealdade, destemor e patriotismo.

Embora sejam histórias sobre heroínas, sublinha-se, na maioria dos casos, o lugar dos personagens masculinos, em especial dos soldados que serviram ao exército em batalhas, alguns deles identificados historicamente como voluntários da Pátria. Servir a Pátria e defendê-la era uma atitude com grande valor simbólico, capaz de motivar também algumas mulheres a seguir para as frentes de combate - como esposas, como enfermeiras ou mesmo compondo batalhões, como ocorre nas histórias analisadas neste texto. De maneira geral, vale apontar que as histórias são curtas e pobres em detalhes factuais, abrindo lugar, no texto, para freqüentes avaliações dos sentimentos e da importância das personagens, para ensinamentos explícitos da história nacional e para a exaltação do 
caráter exemplar das mulheres escolhidas. Destacamos para o presente estudo as histórias de Clara Camarão, Maria Quitéria, Ana Néri e Preta Ana.

\section{As mulheres de Culto Cívico e de Heroínas e Mártires Brasileiras}

Para a presente análise, selecionamos oito textos de Culto Cívico que fazem referência direta à figura feminina e quatro histórias do livro Heroínas e Mártires Brasileiras protagonizadas por mulheres, em cenários de guerra. Na seqüência do trabalho apresentamos as representações de mulher que nos parecem mais expressivas nos textos analisados, reunindo-as em três eixos: mulheres devotadas ao lar e à família, mulheres em contexto de guerra e mulheres consagradas.

\section{Mulheres devotadas ao lar e à família}

Joan Scott (1995) analisa como foram historicamente produzidos determinados espaços sociais como genuinamente femininos, em especial os espaços domésticos, com as tarefas de cuidado da casa e da prole, compondo um "mundo das mulheres" caracterizado pela sensibilidade e delicadeza. E, nesse mundo feminino, a função que é expressa de maneira mais evidente é a maternidade.

São muitos os autores que discutem a atribuição da maternidade à mulher como condição ligada à natureza. Para Pedro (2002), especificamente nas primeiras décadas do século XX, nos estados do Sul do Brasil, onde a doutrina positivista teve larga influência, acrescia-se a esse clichê determinada concepção do lugar da mulher: "a idealização de mães estava presa à missão civilizadora das mulheres, a qual, de acordo com o ideário positivista, deveria ser instruída para aperfeiçoar o esposo e educar os filhos para a humanidade" (p. 293). A mesma autora, entretanto, relembra que os modelos ideais de filhas dedicadas, esposas virtuosas e boas mães já faziam parte do imaginário ocidental, e eram facilmente encontrados na literatura, em sermões religiosos, em textos escolares, e comumente referidos nas tradições locais.

Especificamente nas obras analisadas neste texto, os hinos, poemas e pequenas histórias destacam certos atributos como femininos e instituem a maternidade como condição natural da mulher. Maternidade e patriotismo estão de tal forma articulados, que o amor à pátria parece ter origem no amor materno ou, dito de outra forma, os dois parecem intimamente implicados.

Nesse sentido, o excerto que se segue é exemplar: "procurando incutir em nossos rebentos o sentimento do Amor da Pátria não fazemos mais do que pedir-lhes amor para nós mesmas, que formamos o florido conjuncto de que depende a Família e a Pátria nada mais é do que a reunião da própria família" (Culto Cívico - A Pátria e a Mulher, p. 12).

O lugar social da mulher é o de "filhas, noivas, esposas, mães!" (A Pátria e a Mulher, p. 12), numa ordenação que parece se confirmar nos poemas exortativos e nas narrativas exemplares ${ }^{4}$. Da obra Culto Cívico, os oito textos analisados constroem representações de filhas devotadas, noivas à espera de soldados que partiram para a guerra, mães à espera de seus filhos; soldados que se despedem de suas mães em cartas escritas em contextos de batalha. Os versos de Armando Faria, destacados a seguir, são enfáticos acerca da "missão" feminina: "na família ser Mãe ou Esposa/ É missão tão perfeita e tão santa/ que negal-a, eu creio, ninguém ousa!/ nem culto mais nobre se levanta" (Culto Cívico - Hymno á Mulher, p. 70).

A mulher-mãe é convocada a educar sua família, desenvolvendo nos "rebentos" as virtudes consideradas relevantes naquele contexto: valentia, patriotismo, respeito às 
instituições legais. Nesta família, vista como pedra angular, a mulher é narrada como "absoluta dominadora" e posicionada como partícipe num projeto de futuro da nação:

Muito mais poderoso que o enthusiasmo produzido pelas músicas dos hymnos que fazem vibrar a alma em suas fibras mais profundas; mais forte do que a salutar impressão das orações patriótica em face de sagrados symbolos (...); mais efficaz do que toda educação cívica e disciplinar (...) é o ensinamento do lar. (...) Sem que o alteroso edifício da educação nacional assente nas pedras angulares da família, cujo centro radiante é a mulher, nada de sólido, cousa alguma de permanente será construído (Culto Cívico - A Pátria e a Mulher, p. 12)

A "missão civilizadora" da mulher se corporificaria na educação de seus filhos para a virtude e na produção de homens valentes e fortes no serviço à Pátria, homens capazes de sacrifícios, tal como se pode ler no seguinte excerto: "com vosso sorriso, como vossos beijos (...) conduzi vossos paes, esposos e filhos ao templo da Honra, apontae-lhes o altar do holocausto ao Dever, com a mesma convicção, a mesma crença e o mesmo orgulho com que aquellas fidalgas faziam os jovens cavaleiros jurar sobre o túmulo e as armas de seus queridos antepassados" (Culto Cívico - A Pátria e a Mulher, p. 12). É interessante verificar todo o arcabouço alegórico religioso mobilizado, inclusive com referências às cruzadas medievais - altar, holocausto, juramentos, honra...

As narrativas induzem as mulheres ao sacrifício, à entrega dos filhos à Pátria (entenda-se: à guerra), vista como um feito honroso, em nome de um suposto amor maior devotado ao Brasil. São de D. Rosa da Fonseca as palavras que conclamam as mulheres para essa "causa gloriosa":

Cala-te amor de mãe! Quando o inimigo pisa da nossa Terra o chão sagrado. Amor da Pátria, vivido, elevado, só tu na solidão serás comigo. O dever é maior do que o perigo, pede-te a Pátria, cidadão honrado, vai, meu filho, e, nas lides do soldado minha lembrança viverá contigo. Minh'alma vai toda ahi convosco repartida e eu dou-a (...) Colhe no vasto campo a melhor palma: ou morte honrada ou gloriosa vida! (Culto Cívico - Amor da Pátria, p. 168-169).

O sofrimento é ressignificado como sendo a contribuição feminina à missão da construção da Pátria: fazer calar seu amor de mãe, estimular os filhos (ainda que seja o último dos sete, como lemos em Amor da Pátria) a seguirem o "chamado" da Pátria - a mãe maior, aceitar a dor de ter a alma partida, considerar a morte em combate como honra e o serviço à Pátria como signo de uma vida gloriosa.

Em textos que tematizam momentos cruciais da vida dos soldados (o retorno ou a morte), a referência é à mulher-mãe, tal como se destaca nos dois excertos abaixo:

"Mãe! Minha mãe! Sou eu! Após tantos, cansaços eis-me de volta ao lar, trazendo-te os thesouros do meu amor por ti,oh! mãe idolatrada...

Venho beijar-te as mãos! oh! mãe amargurada..."

Das balas triumphei: trago-te gloria e louros...

Muda, banhada em pranto, ella lhe cahe nos braços.

(Culto Cívico - A Volta do Soldado p.374)

Mãesinha muito amada, a bala traiçoeira, cahiu agora aqui, ferina e carniceira...(...) 
É vosso pobre filho inerme, ensangüentado.

Que morre no seu posto heróico de soldado!

(Culto Cívico - A Carta do Granadeiro, p. 359).

Em Heroínas e Mártires Brasileiras, duas das histórias analisadas também posicionam as protagonistas especialmente como mães, embora essas narrativas desloquem para as frentes de batalha esse exercício de maternidade: a primeira, Ana Néri, é apresentada como uma mulher maternal que deixou o conforto de sua casa para trabalhar como enfermeira em frentes de combate. Conforme se destaca na narrativa, "Era de vê-la, num acanhado hospital de campanha, sem quase tempo de alimentar-se ou repousar, cuidando de feridos e enfermos, desvelada e carinhosa, paciente e maternal". A história desta personagem histórica é assim finalizada: “Tão querida se tornou Ana Néri dos oficiais e soldados, que todos lhe chamavam mãe. Com o dignificante cognome de Mãe dos Brasileiros figura ela nas páginas da nossa história, como um dos mais belos exemplos de abnegação, caridade e amor à pátria" (Heroínas e Mártires Brasileiras - Ana Néri, p. $55)$.

A segunda protagonista de Heroínas e Mártires Brasileiras destacada por seu desvelo maternal é Preta Ana, descrita como "a esposa de um soldado", que suportou sofrimentos junto ao marido, dispondo-se a cuidar, na célebre Retirada de Laguna, dos feridos com desmedido zelo e abnegado amor maternal. Para dar relevo ao altruísmo da protagonista, o narrador destaca que "quando faltaram ataduras, começou a rasgar as próprias vestes para, com as tiras delas arrancadas, estancar o sangue dos bravos que caíam". Devotada ao cuidado dos feridos, ela não se atemorizava "com o estralejar e o espocar do combate, e as balas que lhe silvavam ao redor". Suas ações são apresentadas em contraste às de outras mulheres que "apavoradas, se ocultavam por baixo das carretas de transporte" (Heroínas e Mártires Brasileiras- Preta Ana, p. 62).

\section{Mulheres em contextos de guerra}

Em relação aos textos das duas obras analisadas, é possível afirmar que as mulheres são representadas como sendo o "sexo frágil", delicadas, devotadas ao cuidado do lar e da família, e delas se espera, em primeiro lugar, que assegurem a educação de homens virtuosos e heróicos, futuros voluntários para as batalhas. Mas mais se pode esperar delas em situações de guerra: "até no sexo frágil acende, aviventa e eleva a chamma do civismo" (p. 196), e as mulheres podem chegar a integrar frentes de combate, como se destaca nos versos a seguir, que compõem hino a ser cantado com música de outro hino bastante conhecido há décadas atrás em eventos cívicos:

Nós somos também guerreiras,

Heróicas, bravas,

Da pátria escravas,

Se for preciso ás trincheiras,

Brandindo a espada.

Também correr

Iremos como soldados,

Ó pátria amada

Por ti morrer!

Pois temos também guardados

Deveres santos

Que nos são tantos.

A guerra é triste maldição, 


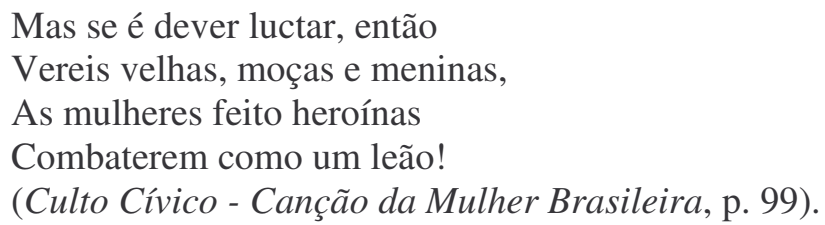

A sequiência da canção destaca que, mais do que tudo, o valor e a nobreza da mulher se manifestam quando ela devota o seu amor incondicional à Pátria. Em outro momento, nesta mesma obra, encontra-se texto do Coronel O. M. Correia, que rememora exemplos de mulheres consideradas virtuosas por tomarem frente em ações de combate, quando a Pátria foi "ultrajada":

Abram-se as páginas de nossa história, onde os exemplos de valor e de abnegação se multiplicam numa affirmativa de amor pátrio.

É Anna Nery, matrona ilustre (...).

É Florisbela, humilde mulher do povo, (...) apparecendo no mais sensível da lucta, transfigurada em anjo de bravura e de coragem.

É Maria Curupati, a menina impúbere, como nova Joana D'Arc, levando as armas de Pernambuco à vitória nos campos paraguaios. (Culto Cívico A Bandeira Nacional, p. 196)

Na obra Heroínas e Mártires Brasileiras, destacam-se as histórias de Clara Camarão, Maria Quitéria e Ana Néri como personagens históricas memoráveis que, superando sua "condição"de fragilidade feminina, se tornam protagonistas em contextos de guerra. Clara Camarão, personagem que protagoniza história de nome idêntico, é uma índia potiguar que participou de batalhas contra os holandeses no Nordeste brasileiro, em meados do século XVII. Na narrativa ela é apresentada como "a esposa do índio Poti Felipe Camarão, herói brasileiro das guerras holandesas" e esse papel coadjuvante é uma referência recorrente: "tal como seu marido, portou-se com heroísmo", "ao lado dele, tomou parte em combates", "conhecida, estimada e respeitada, não só por causa do marido...", "pelejou bravamente junto a seu esposo, a quem auxiliava no comando dos índios". Se a coragem e bravura de Clara Camarão é constantemente referida (embora sem detalhes narrativos), ela é, entretanto, construída como personagem subordinada, que adquire visibilidade pelo fato de estar junto a seu marido, ao lado dele, auxiliando-o. É possível dizer que, mesmo referindo-se a uma mulher, a narrativa naturaliza o cenário como sendo lugar da ação masculina.

Outra protagonista de cenas de combate, apresentada na obra Heroínas e Mártires Brasileiras, é a jovem Maria Quitéria, que participou de lutas relacionadas à Independência do Brasil, em 1822. Para tanto, ela teve de fugir de casa, disfarçar-se de homem, fardandose e passando a integrar um batalhão militar, no qual se destacou pela bravura. $\mathrm{O}$ autor dá relevo a certos atributos ao caracterizá-la: "Tinha essa moça baiana um espírito forte, destemeroso. Era, sobretudo, ardorosa patriota"; "Queria bater-se também. Seu maior desejo, então, foi pegar em arma e atirar-se à guerra"; "Lutou bravamente, heroicamente"; "Distinguiu-se de tal modo que se viu promovida a oficial"

Ocupar-se de guerras era tido uma tarefa masculina, e o fato de Maria Quitéria ter seguido para a guerra, como soldado, constitui uma transgressão: "Deveria, para isso, pedir licença ao pai...[que], com certeza, não consentiria em que ela, uma mulher, se fizesse soldado e fosse combater. Seria um absurdo para ele e toda a família. Coisa inconcebível. Os homens, os moços sim! A eles competia armar-se, partir e enfrentar o adversário"(Heroínas e Mártires Brasileiras - Maria Quitéria, p. 47). 
De acordo com Scott (1995), os lugares sociais femininos e masculinos são historicamente produzidos, cabendo aos homens assumir o controle político, estatal, militar e atuar na esfera pública. Às mulheres caberiam os espaços domésticos, o cuidado da casa e da prole, um "mundo das mulheres", caracterizado pela sensibilidade e delicadeza. Citando Michele Perrot, ela assinala que, desde a Antigüidade, se produzem narrativas sobre mulheres transgressoras, apresentadas em geral como perigosas e desregradas, colocando-se em destaque o risco que representam. Não é esse o caso, entretanto, de Maria Quitéria - seu gesto transgressor é redimido por uma causa maior: o patriotismo. Mesmo transgredindo normas a partir das quais se definiam lugares femininos, ela é considerada uma "autêntica heroína" e suas práticas são narradas como exemplares. Assim, ao final, a narrativa restabelece uma ordem que se deseja salvaguardar nas relações de gênero: a da submissão da mulher ao homem; no caso da mulher solteira, ao pai. Dessa forma, ao ser condecorada pelo Imperador, a heroína lhe pede que envie uma carta a seu pai, dando notícias de seu reconhecimento como "leal servidora da pátria", para que ela pudesse regressar dignamente à casa paterna. A cena é assim descrita:

Lá, no casarão da fazenda de sua família, deu-se então uma cena comovedora: Maria Quitéria, em presença da madrasta e das irmãs [...] ajoelhou-se aos pés do progenitor e lhe pediu a bênção, de cabeça baixa. $\mathrm{O}$ velho Medeiros [...] ergueu as mãos aos céus, pousou-as ambas, ternas e trêmulas, sobre a cabeça pendida de sua filha [...] e abençoou-a. Se a condecoração, no palácio imperial, foi o momento de maior glória na vida heróica daquela mulher famosa, o instante que recebeu ela, com o perdão, a bênção paterna, foi o mais consolador e grato que jamais tivera (Heroínas e Mártires Brasileiras - Maria Quitéria, p. 49-50)

É possível indagar quais sentidos se pretendeu mobilizar ao afirmar que o ato de redenção da protagonista foi presenciado pelas outras mulheres da família: foi "em presença de sua madrasta e irmãs" que Maria Quitéria "ajoelhou-se" e "pediu a bênção de cabeça baixa". Marcam-se nas atitudes corporais - de uma mulher que teria lutado bravamente, num tempo em que a guerra envolvia mobilização direta de corpo e gestos - a humildade e a subserviência. Ao que parece, o autor coloca-nos, como leitores, no lugar dessas mulheres espectadoras, presenciando e aprendendo com o acontecimento.

A terceira história da obra Heroínas e Mártires Brasileiras que põe em relevo a participação feminina em contextos de guerra é a de Ana Néri, que atuou como enfermeira em hospitais de campanha durante a Guerra do Paraguai. A personagem é descrita como uma "mulher instruída, de distinta família", que ofereceu seus serviços ao comando das forças armadas brasileiras. Para sublinhar o heroísmo da personagem o narrador afirma que "dona Ana Néri venceu preconceitos, desprezou conselhos, enfrentou mil desconfortos de viagem" (Heroínas e Mártires Brasileiras - Ana Néri, p.54). Embora a participação das mulheres em contextos de batalha fosse incomum, tornando memorável a escolha feita por Ana Néri, a narrativa posiciona a heroína em relações naturalizadas de gênero: se, por ser mulher de "família distinta" (e, portanto, não "precisando" entregar-se a tais tarefas), ela desafiou preconceitos acompanhando os batalhões, e em suas práticas destacam-se o desvelo, o carinho, a abnegação, a devoção, a relação maternal com os feridos, como parte de uma suposta "essência feminina". A narrativa colabora para fixar posições femininas e masculinas, atribuindo coragem e destemor como exceções, e zelo e dedicação maternal como atributos naturais, colocados, neste contexto, a serviço da pátria. 


\section{Mulheres consagradas - mães da humanidade}

Entre as narrativas de mulheres encontradas nas duas obras das primeiras décadas do século XX, destacam-se ainda aquelas que posicionam as mulheres num serviço generoso, piedoso, voluntário, como autênticas mulheres consagradas. As Irmãs de Caridade são referidas em dois dos oito textos de Culto Cívico e são neles qualificadas como "anjos na terra". No poema Irmãs, o autor conclama o/a leitor/a a observá-las "nos hospitaes, nas brenhas e na escola", em "nobre e puro apostolado". São chamadas de "noivas de Christo" - epíteto comum para freiras - cujo trabalho seria "enxugar toda lágrima que rola", exercendo o amor e o carinho. O poema se encerra articulando a vocação religiosa com a maternidade. Como não podem ter filhos, devido ao regramento das ordens religiosas, tais mulheres precisariam ser posicionadas em seu papel maternal (afinal, ser mulher é ser mãe!) de outra forma. É então que o/a autor/a resolve o impasse: "Que amôr o d'essas mães da humanidade!/Cada infeliz é-lhes um ser dilecto.../ São seus filhos a criança, o índio, o infermo/ Tem o nome de Irmãs... são mães no affecto!" (p. 377).

É interessante observar quem são os sujeitos aos quais se destinam os cuidados maternais das irmãs: os infelizes, os carentes, os miseráveis - e, nesta parte do poema, as crianças (em orfanatos), os índios (considerados nesta época relativamente incapazes e portanto passíveis de tutela) e os enfermos (aos quais as irmãs devotariam cuidados em hospitais). No excerto abaixo destacam-se a abnegação e zelo das irmãs na enfermaria dos Hospitais de Campanha:

Querida mãe, estou bem aqui, na enfermaria,

A cama é boa. A irmã, que vela todo o dia,

Tem tudo arrumadinho. A touca bem brunida,

E os grandes olhos bons, lembrando a Margarida.

Sabes? - Ella não quer que o diga - é titular,

Condessa ou cousa assim, mas sabe conjugar

Em todo o tempo, modo e número e pessôa,

o doce verbo amar, esta enfermeira boa!

Olha por mim tão bem como si filho fora,

Sorri quando eu sorrio, e quando eu chóro, chóra...

Traz-me as ligas, a gaze, arsênico, sulfato,

compra lá longe o chá, que é muito mais barato!

(Culto Cívico - A Carta do Granadeiro p. 359).

Esse tipo de narrativa reafirma o lugar feminino no cuidado da prole - filhos naturais ou filhos de afeto - constituindo a maternidade como atributo natural e condição de feminilidade. No caso das mulheres-irmãs, além do cuidado e zelo, a piedade e a empatia são acentuadas como atributos valorosos.

\section{Palavras finais}

Os poemas, hinos e histórias publicadas nas duas obras analisadas certamente colaboraram para governar as práticas dos leitores e das leitoras, que supostamente seriam estimulados a cultivar o "amor pátrio" através desses e de muitos outros exemplos de patriotismo, reiteradamente construído pelas alusões à defesa da Pátria contra "o inimigo". E não apenas os homens eram chamados a este serviço - como soldados ou futuros soldados $^{5}$; às mulheres - desde que respeitada sua "condição feminino-materna" - também tal prerrogativa seria concedida. Assim figuram as mulheres: gerando filhos, neles incutindo os valores do patriotismo e da honradez, permitindo que eles integrassem os 
batalhões belicosos, engolindo a dor da separação, estariam provendo a Pátria do que ela precisaria - braços para a luta; figuram ainda como "mulheres consagradas" à piedade e ao cuidado daqueles que delas precisam, mesmo não sendo "mães de sangue"; por fim, há a possibilidade de, "como leoas", elas mesmas lutarem nas frentes de batalhas, uma vez que o amor a pátria seria incondicional.

Trata-se, então, da produção de representações de mulheres heroínas e "cultuadas" como quase santas, que atuam no "mundo masculino" (público, bélico), sem no entanto colocar em questão as qualidades tidas como "próprias" do "mundo feminino". O excerto a seguir parece ilustrativo:

Para que um povo seja respeitado e grande é preciso que a mulher, a sublime obra do Creador, a absoluta dominadora do lar, seja a imagem sacrosanta do Dever, a christallisação perfeita do Amor submisso e heróico, que se desvela pelos entes queridos e ao mesmo tempo lhes incita à pratica das maiores virtudes, apontando-lhes o caminho da Honra, com o sacrifício, embora de seus mais caros sentimentos affectivos, com a abnegação de uma estoica e a resignação de uma santa (Culto Cívico - $A$ Pátria e a mulher, p. 12).

Os textos analisados de Culto Cívico e Heroínas e Mártires Brasileiras não apenas descrevem acontecimentos e histórias protagonizadas por mulheres: eles colaboram para naturalizar determinados atributos femininos e para produzir certo jeito de ser mulher em contextos de combate e de guerra. Inserindo-se no que se poderia chamar de uma "ideologia nacionalista e ufanista", corrente na época em que foram escritos, eles ensinam sobre patriotismo, como sentimento primordial que impulsiona atitudes de heroísmo, e colaboram para fixar certas práticas como desejáveis, tais como o cultivo do "amor pátrio" e a dedicação ilimitada. Para tanto, lançam mão desses e de muitos outros "exemplos edificantes" contidos nos textos dessas duas obras literárias e de outras mais de seu tempo.

Se retomarmos as idéias de Shavit com as quais abrimos este texto, podemos entender e aceitar com menos rigor crítico a existência de tais obras no contexto brasileiro em que elas foram publicadas. A autora, ao efetuar a análise de várias versões de Chapeuzinho Vermelho" ${ }^{6}$ afirma que "suas numerosas versões (...) revelam de um modo muito claro os diversos modos como a infância foi vista pela sociedade em diferentes períodos, não apenas na avaliação da capacidade de compreensão da criança como também na convicção da sociedade quanto às coisas a que a criança devia ser exposta" (2003, p. 27). Ainda que não tenhamos nos debruçado sobre diferentes versões de uma mesma história, podemos ler os textos que acabamos de analisar como reveladores de uma idéia social de criança, de um ideal de formação dessa criança para o futuro e de um ideário de como deveria ser este futuro em termos de nação; por fim, também está operacionalizada em tais textos uma concepção de quais leituras melhor colaborariam para tal formação. Nesse sentido, não foi nosso objetivo aquilatar sua literariedade ou sua qualidade estética, também elas dimensões que sofrem nuances e redefinições históricas e culturais, assim como entendemos que as representações de feminino que os textos realçam podem ser consideradas como integrantes de uma determinada ideologia dominante na época, conforme a qual também as mulheres eram fortemente convocadas para a construção da nova nação.

\section{Referências}

CARVALHO, José Murilo de. A formação das almas - o imaginário da República no Brasil. São Paulo: Companhia das Letras, 1990. 
GUIMARÃES, Lucia Maria Paschoal (2007). Henrique Fleiüss: vida e obra de um artista prussiano Corte (1859-1882), disponível

em http://sitemason.vanderbilt.edu/files/lretmo/Guimaraes\%20Lucia.doc. Acesso em 09 de agosto de 2007.

HALL, Stuart. The work of representation. In: (org.). Representation, cultural representations and signifying practices. London: Thousands Oaks; New Delhi: Sage, 1997.

HARTLEY, John. Comunicação, Estudos Culturais e Media - conceitos-chave. Coimbra: Quimera, 2004.

LAJOLO, Marisa; ZILBERMAN, Regina. Literatura infantil brasileira: história \& histórias. São Paulo: Ática, 1985.

LEÃO, Andréa Borges. Brasil em imaginação: livros, impressos e leituras infantis (1890-1915). Disponível em http://www.intercom.org.br/papers/nacionais/2003/www/pdf/2003_NP04_leao.pdf Acesso em 08 de agosto de 2007.

MARTINS, Ari. Escritores do Rio Grande do Sul. Porto Alegre: Instituto Estadual do Livro UFRGS, 1978.

PEDRO, Joana Maria. Mulheres do Sul. In: PRIORE, Mary del (Org). História das Mulheres no Brasil. São Paulo: Contexto, 2002.

SCOTT, Joan. Gênero: uma categoria útil de análise histórica. In: Educação \& Realidade, Porto Alegre, v. 20, n. 2. (jul./dez. 1995), p. 71-99.

SILVA, Tomaz Tadeu da. Teoria cultural e educação - um vocabulário crítico. Belo Horizonte: Autêntica, 2000.

SOUZA, Rosa Fátima de. Templos de civilização: a implantação da escola primária graduada no estado de São Paulo (1890-1910). São Paulo: Fundação Editora da UNESP, 1998.

SHAVIT, Zohar. Poética da Literatura para Crianças. Lisboa: Editorial Caminho, 2003.

TRINDADE, Iole Faviero. A invenção de uma nova ordem para as cartilhas - ser natural, maternal e mestra. Queres ler? Bragança Paulista: Editora Universitária São Francisco, 2004.

\section{Livros analisados}

FLEURY, Renato Sêneca. Heroínas e Mártires Brasileiras. Melhoramentos, s/d.

GOMES, J.R. Moreira. Culto Cívico e Pedagogia. Pelotas: Livraria ${ }^{1}$ Americana, s/d.

\footnotetext{
${ }^{1}$ A tradução do original é de Ricardo Uebel.

${ }^{2}$ Localizamos dois outros exemplares da mesma obra. Um, datado de 1918 e com a indicação de ser $5^{\text {a }}$ edição, referida à cidade de Pelotas (e não Rio Grande, como afirma Martins), consistindo em exemplar com menos textos do que o que analisamos, mas com o mesmo espírito. Outro exemplar foi localizado no acervo da biblioteca da UNISINOS (São Leopoldo, RS) e nele se encontra a referência de $1^{\text {a }}$. Edição, com data de 1932, o que poderia indicar a mudança de editora e uma nova contagem de edições.

${ }^{3}$ Dados obtidos em VOGT, Olgário. Germanismo e nacionalização em Santa Cruz do Sul. Disponível em www.unisc.br/universidade/estrutura_administrativa/nucleos/npu/npu_patrimonio/producao_cientifica/unisc/ artigos/germanismo-nacionalizacao.pdf. Acesso em 30 de julho de 2007.

${ }^{4}$ No poema A Carta do Granadeiro, em que o autor simula um longo solilóquio de um soldado ferido, reativando lembranças e, de certa forma, prevendo seu fim (inclusive onde seria enterrado), há referência a
} 
uma mulher amada - Margarida - que estaria esperando o soldado moribundo. Este, inclusive, pede que a mãe comunique à amada a sua morte e os seus pensamentos nela naquele momento.

5 Trindade (2004, p. 400) traz reprodução de figura e texto da "Cartilha analytica", de Arnaldo Barreto, de 1930, utilizada no Rio Grande do Sul. A página exibe a estampa de um menino tocando tambor e, no texto anexo, lê-se o diálogo: “-Você gostaria de ser soldado? - Eu gostaria, oh! Sim, de ser soldado. Eu gostaria de defender o meu querido Brasil. Eu gostaria de ser um soldado valente." Outras duas folhas de outras cartilhas também ali reproduzidas mostram como o ideal de "ser um soldado" parecia ser muito precocemente induzido nos meninos do período.

${ }^{6}$ Como a tradução é lusa, a referência é a "O Capuchinho Vermelho".

Artigo recebido em: 13/11/08

Aprovado para publicação em: 31/07/09 